\title{
Contrasting rainfall-runoff characteristics of floods in desert and Mediterranean basins
}

\author{
Davide Zoccatelli ${ }^{1}$, Francesco Marra ${ }^{1}$, Moshe Armon ${ }^{1}$, Yair Rinat ${ }^{1}$, James A. Smith $^{2}$, and Efrat Morin ${ }^{1}$ \\ ${ }^{1}$ Institute of Earth Sciences, Hebrew University of Jerusalem, Jerusalem, Israel \\ ${ }^{2}$ Department of Civil and Environmental Engineering, Princeton University, Princeton, New Jersey, USA
}

Correspondence: Davide Zoccatelli (zoccatelli.davide@gmail.com)

Received: 28 October 2018 - Discussion started: 5 November 2018

Revised: 11 April 2019 - Accepted: 4 May 2019 - Published: 21 June 2019

\begin{abstract}
Catchment-scale hydrological studies on drylands are lacking because of the scarcity of consistent data: observations are often available at the plot scale, but their relevance for the catchment scale remains unclear. A database of 24 years of stream gauge discharge and homogeneous highresolution radar data over the eastern Mediterranean allows us to describe the properties of floods over catchments spanning from desert to Mediterranean climates, and we note that the data set is mostly of moderate intensity floods. Comparing two climatic regions, desert and Mediterranean, we can better identify specific rainfall-runoff properties. Despite the large differences in rainfall forcing between the two regions, the resulting unit peak discharges and runoff coefficients are comparable. Rain depth and antecedent conditions are the most important properties to shape flood response in Mediterranean areas. In deserts, instead, storm core properties display a strong correlation with unit peak discharge and, to a lesser extent, with runoff coefficient. In this region, an inverse correlation with mean catchment annual precipitation suggests also a strong influence of local surface properties. Preliminary analyses suggest that floods in catchments with wet headwater and dry lower section are more similar to desert catchments, with a strong influence of storm core properties on runoff generation.
\end{abstract}

\section{Introduction}

Drylands cover one-third of the world's lands (Safriel et al., 2005). Their extent has been increasing in recent years due to changing climate, land overexploitation and soil erosion, and it is expected to expand approximately by $10 \%$ before the end of the 21st century (Cherlet et al., 2018; Feng and Fu, 2013; Safriel et al., 2005). Drylands cover a wide range of climate, tectonic, structural, lithological and phytological settings but share similarities in hydrological processes (Tooth and Nanson, 2011). Hydrological studies on drylands are lacking, despite the large importance of water resources in these areas (Pilgrim et al., 1988; Tooth, 2000). In comparison with temperate regions, drylands are generally underpopulated, with lower economic interests and, consequently, sparser data records. Precipitation is characterized by a very high spatial and temporal variability, and runoff generation is localized (Osborn et al., 1972). The lack of data, in combination with the need of data at high resolution, is the main obstacle to the development of hydrological studies on drylands, particularly at the catchment scale.

\subsection{Hydrology of drylands}

With drylands we refer to a range of climates spanning from Mediterranean to deserts, as presented in Sect. 2.1. Most hydrological studies on drylands are derived using sparse data sets, with few exceptions in the southwestern United States (Goodrich et al., 2000; Renard et al., 2008), Australia (Tooth, 2000), southern Spain (Cantón et al., 2011) and the eastern Mediterranean region (Bahat et al., 2009; Schick et al., 2000). In this paper we focus on the characteristics of dryland floods. Since dryland river beds are dry for most of the year, floods are defined as runoff events that bring water into the channel (Graf, 1988). Localized convective storms have an important role in these floods, and the runoff production has been shown to be sensitive to the small-scale characteristics of convective cells (Fiener and Auerswald, 2009; Morin et al., 2006; Morin and Yakir, 2014). Most con- 
vective rainfall cells in the drylands of the eastern Mediterranean have an area up to $300 \mathrm{~km}^{2}$, move with velocities up to $25 \mathrm{~m} \mathrm{~s}^{-1}$ and live up to $50 \mathrm{~min}$ (Belachsen et al., 2017; Marra and Morin, 2018; Peleg and Morin, 2012). In the Dead Sea region, the area of convective cells has been observed to increase with latitude, following orography, while their rain intensity remained unaffected (Belachsen et al., 2017). At the hillslope scale, soil crusting and aggregation (Singer and Le Bissonnais, 1998; Yair, 1990), stone disposition (Abrahams and Parsons, 1991; Dunkerley, 1995; Poesen et al., 1990), vegetation (Faulkner, 1990; Francis and Thornes, 1990; Tongway and Ludwig, 1994; Ludwig and Tongway, 1995; Puigdefábregas, 2005; Thornes, 1985) and microtopography (Bergkamp, 1998; Dunne et al., 1991) have been observed to influence runoff generation in drylands. The combination of high rain intensity, low vegetation interception and low soil infiltration capacity increases the importance of infiltration excess (Hortonian) overland flow (Wheater et al., 2007). In semi-arid regions, Cantón et al. (2011) describe runoff generation as a mix combining Hortonian runoff and saturation flow from topsoil. Because of the low soil water capacity, baseflow is low, and most of the water infiltrating the hillslopes is evaporated (Renard et al., 2008). Runoff generation on hillslopes is spatially and temporally localized and, especially during low flows, can reinfiltrate before reaching the base of the hillslopes (Yair and Raz-Yassif, 2004). Factors such as temporal rainfall structure, antecedent moisture and vegetation are known to affect the connectivity of runoff sources to channels (Marchamalo et al., 2016; Reaney et al., 2007). The presence of Hortonian overland flow means that runoff can be generated also by small contributing areas, resulting in high drainage density, estimated by Reid and Frostick (1987) to a maximum of $100 \mathrm{~km} \mathrm{~km}^{-2}$. The propagation through dry channels, however, causes part of the runoff to infiltrate along the river bed, a process called transmission losses. The volume of water infiltrating the channel depends on the properties of the storm (size, position), hydrograph (volume, duration) and channel (width, porosity, initial conditions, stratigraphy), and it is particularly important in alluvial areas (Morin et al., 2009b; Tooth, 2000).

For many hydrological applications it is important to know the properties of the flow at the catchment scale, while the hydrological processes described above are generally observed at the plot scale. Most of these processes are involved in shaping the hydrograph at the outlet, but their relative importance, interactions and feedbacks, often resulting in nonlinear dynamics, are very difficult to predict (Cantón et al., 2011). Despite the wide variety of dryland environments, their unique processes can result in unique flood properties at the catchment scale (Tooth, 2000). Floods in arid areas are characterized by short durations (Keppel and Renard, 1962). During extreme storms, event-based runoff coefficients and unit peak discharge can reach values comparable to wetter climates, especially in small basins (Amponsah et al., 2018;
Costa, 1987; Tarolli et al., 2012), and respond mostly to the intensity and volume of the storm core (Syed et al., 2003). The resulting flood frequency distribution is skewed, with a high ratio of large to small floods (Farquharson et al., 1992; McDermott and Pilgrim, 1983). Analyzing the upper tail of flood distribution, Smith et al. (2018) found that arid and semi-arid areas have an upper tail ratio, defined as the extreme peak discharge divided by the 10-year flood magnitude, which is significantly higher than wetter climates.

\subsection{Objectives}

A characterization of the common rainfall-runoff properties of drylands catchments is needed, but it has to be carried out at a high spatial and temporal resolution (Beven, 2012; Faurès et al., 1995; Syed et al., 2003). A unique radar rainfall database with $1 \mathrm{~km}^{2}$ and $5 \mathrm{~min}$ resolution, uniformly covering 24 years, is available for the eastern Mediterranean region (Marra and Morin, 2015). This database, in conjunction with stream gauge measurements, can improve the understanding of catchment-scale hydrology in these environments. The use of operational stream gauges has high uncertainties and limits the analysis to moderate storm events, but it allows us to analyze a large number of floods and basins and to capture their common properties. Specifically, in this paper we are comparing catchment-scale data from desert and Mediterranean environments in order to characterize their unique rainfall-runoff properties. In each of these climates we try to identify the main factors related to peak discharge and runoff generation and which processes have an important effect at the catchment scale.

\section{Study region and data}

\subsection{Climatic regime}

Figure 1 shows how, under the Köppen-Geiger climate classification (Köppen, 1936; Peel et al., 2007), the eastern Mediterranean region under study ranges from hot-summer Mediterranean (Csa), to hot semi-arid (BSh) and to hot desert climate (BWh). The region is located between 30 and $33^{\circ} \mathrm{N}$, where the descending air from Hadley and Walker circulation cells intersects and prevents rain-bearing clouds throughout the summer (Dayan et al., 2017; Kahana et al., 2002; Ziv et al., 2004). Rain seasonality is strong, with most of the rain occurring between October and May, and summers are dry (Goldreich, 1994). Rain is caused mostly by cold fronts and postfrontal systems associated with midlatitude cyclones over the eastern Mediterranean, usually lasting for $2-3 d$, connected with local intensive convection (Goldreich, 2003; Peleg and Morin, 2012). The effect of midlatitude cyclones decreases from north to south. Less frequently and affecting mostly the southern and eastern part of the study area, a surface low-pressure trough extending along the Red Sea and supported by an upper level trough brings localized con- 


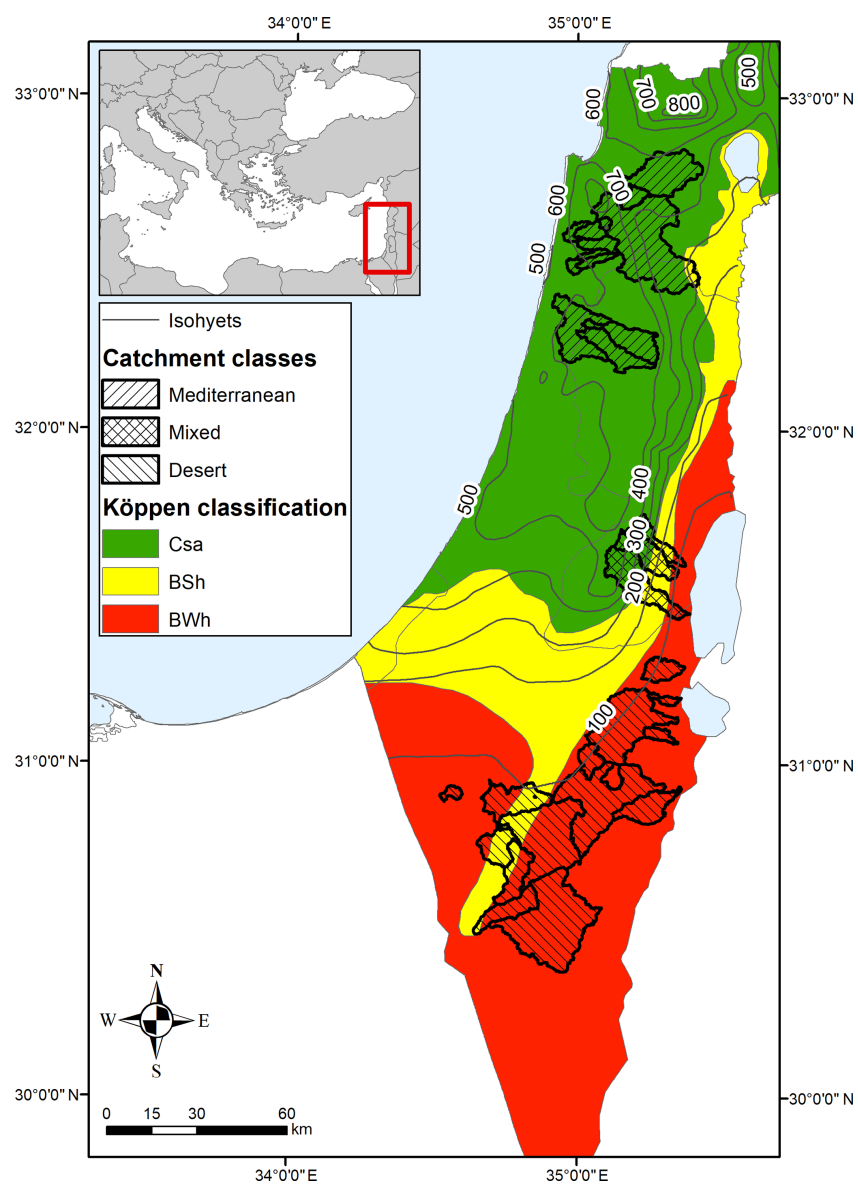

Figure 1. Köppen-Geiger climate classification from Survey of Israel (1970), mean annual precipitation (1981-2010, Israel Meteorological Service) and catchment climatic classes.

vective showers in the area, mostly occurring after the daily thermal maximum, in the afternoon (active Red Sea trough ARST) (Sharon and Kutiel, 1986; De Vries et al., 2013). On rare occasions a conveyor belt of moisture in the mid-upper tropospheric layers causes widespread rainfall over the whole region (Armon et al., 2018; Rubin et al., 2007). Mean annual precipitation shows a north-to-south gradient, from 700 to less than $50 \mathrm{~mm} \mathrm{yr}^{-1}$, caused by the different occurrence and intensity of Mediterranean cyclones and the shape of the Mediterranean shoreline, and a west-to-east sharp gradient caused by the shading effect of the Judean Mountains.

\subsection{Geomorphology of the region}

The study area is located in the eastern Mediterranean region and can be divided into three groups along $300 \mathrm{~km}$ in a north-to-south direction (Fig. 2). The northern part is located around Mt. Carmel, between Galilee and the coastal plain, with a hilly morphology draining west. The lithology is dominated by carbonate units, including mostly limestones, dolostones and chalks, with thin soils and patches of exposed bedrock (Grodek et al., 2012). The area has a long history of intensive cultivation that reduced soil depth and resulted in many abandoned terraces. The landscape is dominated by cultivations and areas covered by dwarf-shrub steppe (Rinat et al., 2018). With few exceptions, streams are mostly ephemeral. In the center, the Judean Mountains drain eastward from around $1000 \mathrm{~m}$ above sea level (a.s.l.) to less than $-400 \mathrm{~m}$ a.s.l. of the Dead Sea. This creates elongated basins with a wet headwater and dry lower section. Along the Judean ridge, the exposed Upper Cretaceous carbonate rocks form narrow gorges crossing from the headwater to the Dead Sea. Their eastward rainfall gradient corresponds also to a gradient of soil development and infiltration capacity (Greenbaum et al., 2006). The mountain ridge is occupied by few large cities and cultivated areas, while the downstream area is uncultivated and with a low vegetation cover. The south of the region consists of the Negev, a sparsely populated rocky desert. The geology is characterized by a heterogeneous combination of several stratigraphical groups, with different hydraulic properties (Shentsis et al., 1999). Loesscovered areas are more extensive in the northern semi-arid part of the Negev rather than the central arid part, where sandy and rocky yermic soil prevail (Yair and Kossovsky, 2002). Urban areas are sporadic, and most of the land is uncultivated with a low vegetation cover.

\subsection{Basin selection}

Basins from different climatic regions were selected to highlight their unique flood properties. The main criteria for basin selection were the localization within the radar range and discharge data availability between 1991 and 2014, as explained in Sect. 2.4. The selection resulted in 30 basins, with an area ranging from 12 to $1232 \mathrm{~km}^{2}$ (Fig. 1). The distinction in three groups was done following the Köppen-Geiger climate classification (Fig. 1). Most basins are well located inside the Mediterranean or desert climate. Because of the extremely strong precipitation gradients, few basins extend from Mediterranean to desert climate. These basins, named "mixed" from now on, are on the lee side of the Judean Mountains, with a wet headwater and a strong climatic gradient along the catchment. Despite the fact that only three of such basins are available in our sample, we decided to analyze them separately. In fact, their conditions are common to other areas of the world, but flood properties are not well represented in the literature. Since they include mixed climatic and hydrological conditions, understanding their flood regime is not trivial. The resulting basin classification includes 13 Mediterranean, 3 mixed and 14 desert basins (Fig. 1). The characteristics of the three basin classes are reported in Table 1. Among them are the relief ratio, defined as the ratio between the total relief of a basin and its longest dimension parallel to the principal drainage line; and elongation ratio, which is the ratio between the diameter of a circle with the same area as the basin and the maximum length of 


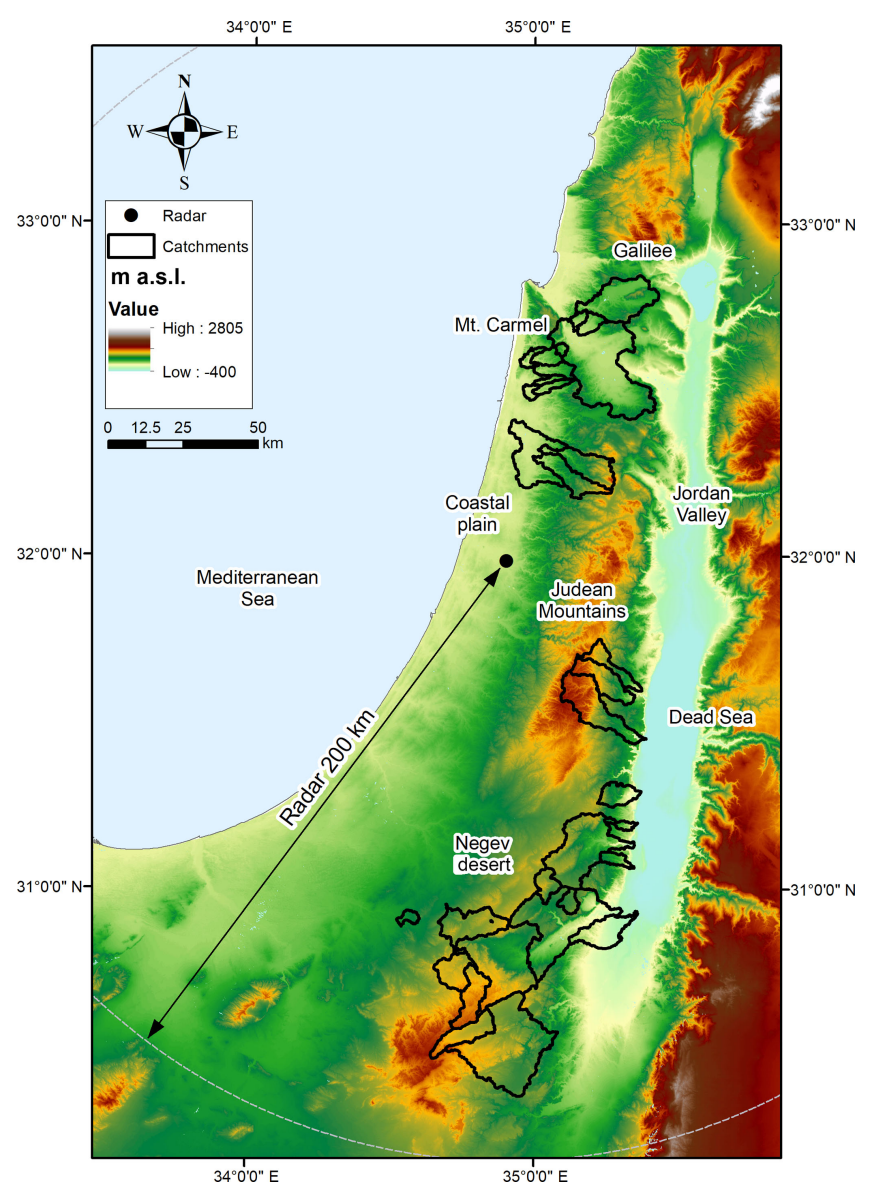

Figure 2. Study area and the outline of the catchments analyzed.

the basin (Schumm, 1956). While mean annual precipitation (MAP) in desert and Mediterranean basins is largely different, area, elongation ratio and relief ratio are comparable. In the Negev desert, Meirovich et al. (1998) report a correlation between mean annual precipitation and number of events per year. Mixed basins are generally more elongated and have a frequency of floods closer to deserts.

Flood seasonality in the three climatic classes is reported in Fig. 3. As expected at these latitudes, the seasonality is very marked, with more floods in winter and a dry summer season. The comparison between classes does not highlight differences in the climatic forcing. Mediterranean floods seem to be slightly more common from December until February (78\%) than desert floods (66\%), while transitionalseason floods' frequency is higher in the desert and mixed basins. This reflects the higher frequency of ARST circulation patterns during fall and spring (Kahana et al., 2002). An analysis of seasonality over basin size did not show any significant difference, indicating that basins of different size are activated by similar circulation patterns.

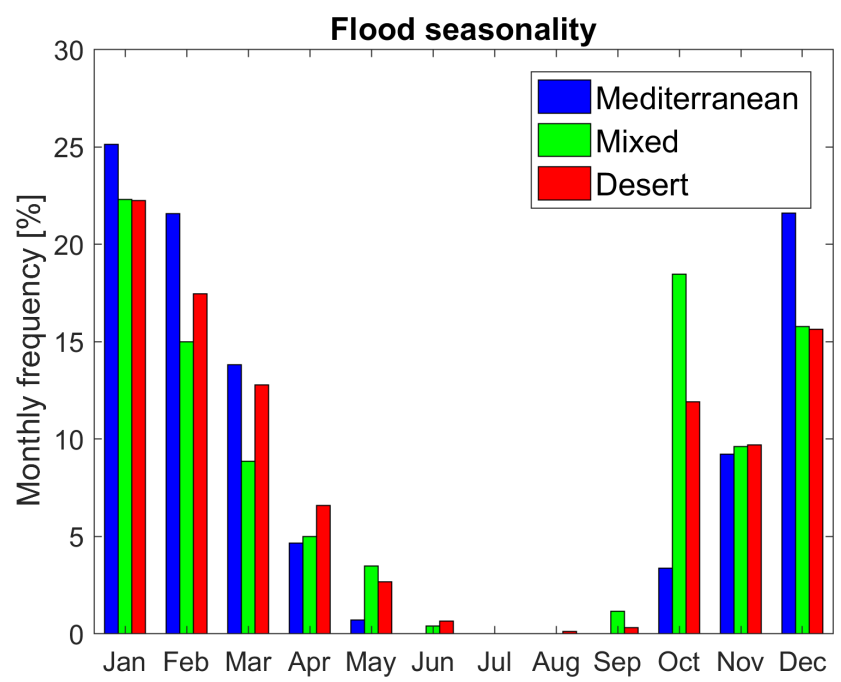

Figure 3. Monthly distribution of floods in the climatic classes.

\subsection{Data available and uncertainties}

For this study we used streamflow data from the hydrometric stations of the Israel Hydrological Service (IHS) (Israeli Hydrological Service, 2016). The division into single flood events was performed by IHS, in most cases when the flow is ceased (in ephemeral channels) or when it decays to baseflow levels. Radar data from the Shacham weather radar, located in the Ben Gurion Airport (Fig. 2), are used. The radar is a non-Doppler C-band system operational from the 1990s until 2014. Corrections and gauge adjustments have been performed, resulting in a homogeneous archive of precipitation estimates with $1 \mathrm{~km}^{2}$ and 5 min resolution from 1990 to 2014 (Marra and Morin, 2015). Rain gauge data from subsets of 808 daily stations of the Israel Meteorological Service were later employed to locally adjust the radar estimates, as explained in the next paragraph. For each flood, rainfall was analyzed from $2 \mathrm{~d}$ before the start of runoff until its end. The remarkable length and resolution of rainfall and streamflow databases allow us to compare flood properties across a large sample. However, this comes at the price of dealing with significant uncertainties at the single-event scale, which should be kept in mind throughout the analysis. The main issues related to radar data can be identified in shutdowns, estimation of high intensities and local bias. During the 24 years of radar rainfall availability the system was occasionally inactive, resulting in potentially missing intervals during storms. Convective storms may include hail, which is characterized by a high reflectivity that compromises the ability of the radar to estimate precipitation intensity. Regarding local bias, despite the corrections described in Marra and Morin (2015), locally, data can still have a significant bias. A further local multiplicative mean field bias correction is performed independently for each flood, using data from daily rain gauges located within $20 \mathrm{~km}$ from each 
Table 1. Summary of basin properties (minimum and maximum) in the three regions.

\begin{tabular}{lrrrrrr}
\hline Climatic class & Basins & $\begin{array}{r}\text { MAP } \\
\left(\mathrm{mm} \mathrm{yr}^{-1}\right)\end{array}$ & $\begin{array}{r}\text { Area } \\
\left(\mathrm{km}^{2}\right)\end{array}$ & $\begin{array}{r}\text { Relief ratio } \\
\left(\mathrm{m} \mathrm{m}^{-1}\right)\end{array}$ & $\begin{array}{r}\text { Floods per } \\
\text { year }\left(n \mathrm{yr}^{-1}\right)\end{array}$ & $\begin{array}{r}\text { Elongation } \\
\text { ratio (-) }\end{array}$ \\
\hline Mediterranean & 13 & $531-686$ & $13-692$ & $0.012-0.04$ & $4.9-15.8$ & $0.30-0.65$ \\
Mixed & 3 & $306-340$ & $80-233$ & $0.04-0.05$ & $2.8-4$ & $0.29-0.36$ \\
Desert & 14 & $46-150$ & $20-1232$ & $0.011-0.07$ & $1.5-4.7$ & $0.31-0.59$ \\
\hline
\end{tabular}

basin. The rain gauge density is higher in the north, while for the southern basins the density drops. For consistency, the southern rain gauge density of $1 / 250 \mathrm{~km}^{2}$ is used, by excluding stations in areas with higher rain gauge density. The application of mean field bias has proven to significantly improve radar rainfall estimations during flash floods (Yang et al., 2017), but large uncertainties in rainfall volume may remain. The final radar precipitation estimations have a 0.81 correlation with daily rainfall from rain gauges and a fractional standard error (see Marra and Morin, 2015) of 0.43. Regarding streamflow data, the uncertainties related to the use of operational stations can be identified in the estimation of high flows, low flows and timing. When water level is higher than the range used to calibrate the stage-discharge relation, the extrapolation can be affected by significant error if no specific corrections are applied. Low flows are often at the lower end of stream gauges' sensitivity and can be affected by high relative errors. Lastly, the early use of mechanical stream gauges, which required the digitization of charts, resulted in inaccurate flood timing estimates that can range from few hours up to $1 \mathrm{~d}$ (Morin et al., 2009b). Records of 5534 floods are available on the selected basins. To ensure a minimum quality of single events, we performed an evaluation based on multiple criteria. Accepted floods need to have radar coverage before the peak and correspondence with rain gauge cumulate precipitation in the days before the flood. At least two rain gauges need to be recording more than $10 \%$ of the mean catchment rainfall during the storm. Hard thresholds were used for automatic selection, but their values were voluntarily loose and subjective judgment was used for controversial events. Runoff peaks and catchment rainfall should be above a minimum threshold $\left(0.5 \mathrm{~m}^{3} \mathrm{~s}^{-1}\right.$ and $3 \mathrm{~mm}$, respectively), and the runoff coefficient should not exceed unity. Despite significantly reducing the sample, we believe that this selection is necessary to ensure a minimum quality of the analyzed data. After the selection process, 1538 floods are left: 1277 in Mediterranean basins, 73 in mixed and 188 in desert. Because of the larger number of floods per year (Table 1) and rain gauge density, the sample is larger for Mediterranean basins. It should be noted also that, because of how the analysis is structured, the floods included are mostly of moderate intensity. Flood extremes are rare in stream gauge records, and only $2 \%$ of the analyzed floods have a unit peak discharge larger than $1 \mathrm{~m}^{3} \mathrm{~s}^{-1} \mathrm{~km}^{-2}$. This is about 10 times less than the extreme events in this region (Tarolli et al., 2012). The highest unit peak discharge included in the analysis is $3.4 \mathrm{~m}^{3} \mathrm{~s}^{-1} \mathrm{~km}^{-2}$. To understand the magnitude of single events, we have estimated their return period using the generalized extreme value distribution. The parameters of the distribution are computed using the probability-weighted moments (Katz et al., 2002) on stream gauges with more than 10 years of data. We have isolated 122 floods with more than 5 years of return period and used them as a sample to understand the behavior of larger floods. The complete database of flood properties created for this research is available in Zoccatelli et al. (2019).

\section{Results and discussion}

\subsection{Flood characterization: rain}

To represent the characteristics of the flood-generating rainfall in the three regions, the radar rainfall estimates are analyzed. Similarly to Marchi et al. (2010), rainstorm duration is defined as the temporal duration of the runoff-generating rainfall episodes, separated by more than $6 \mathrm{~h}$ of rainfall hiatus. Maximum rain intensity is the storm maximum rain intensity over a moving window of $1 \mathrm{~h}$, recorded over an area of $3 \mathrm{~km} \times 3 \mathrm{~km}$. The area has been selected as representative to describe the high intensity core of rain cells by Syed et al. (2003). Similar analyses over different durations $(10 \mathrm{~min}, 30 \mathrm{~min}, 1 \mathrm{~h}, 2 \mathrm{~h})$ and areal extents $(1,4,9$, $16 \mathrm{~km}^{2}$ ) showed consistent results. Antecedent rainfall is the total depth of catchment rainfall in the $10 \mathrm{~d}$ before the floodgenerating storm, as calculated from the adjusted radar data. The $10 \mathrm{~d}$ interval is a compromise, since in arid areas most water in the upper soil layer disappears quickly (Syed et al., 2003), while in the Mediterranean region shorter intervals can miss previous significant rainfall. Results are found to be consistent for intervals between 10 and $30 \mathrm{~d}$. Rain core depth is the amount of 10 min rainfall that fell with intensity above $25 \mathrm{~mm} \mathrm{~h}^{-1}$, expressed in millimeters $(\mathrm{mm})$ over the basin. A similar statistic has been reported by Syed et al. (2003) to be significant in explaining runoff production in arid basins together with rain core coverage. Rain core coverage is calculated as the fraction of basin covered by $10 \mathrm{~min}$ rainfall above $25 \mathrm{~mm} \mathrm{~h}^{-1}$ at any moment during the storm. The dimensionless statistics of storm rainfall spatial position and concentration $\left(\Delta_{1}\right.$ and $\Delta_{2}$, respectively) are calculated as in Zoccatelli et al. (2011). These statistics describe rain- 
fall organization over the catchment as seen through the filter of the river network and are used to highlight properties of rainfall that have an effect on runoff response. Similar statistics are used by Smith et al. (2005) to analyze the effect of rainfall structure on flood response. Values of $\Delta_{1}$ higher and lower than 1 indicate respectively storm rainfall positioned near the headwater or close to the catchment outlet. Values of $\Delta_{2}$ lower than, equal to or higher than 1 indicate respectively storm rainfall concentrated, uniformly distributed or with two peaks within the catchment. The use of dimensionless statistics allows us to compare rainfall position between basins of different size and shape.

There is a clear pattern in most rainfall properties between Mediterranean, mixed and desert basins (Fig. 4). In Mediterranean basins, storms have about 3 times as much rain depth and duration than deserts. The longer duration of Mediterranean storms compared with Marchi et al. (2010) and Tarolli et al. (2012) can be attributed not only to including strong localized storms but all runoff-generating storms in the region. In Mediterranean basins maximum local rain intensities are stronger, and rainfall is relatively uniform over the basin. Higher local intensities are expected in Mediterranean basins when analyzing moderate events, as in the present study. Instead, the highest rainfall intensities for extreme events have been observed in desert areas (Marra and Morin, 2015; Morin et al., 2009a). In deserts, duration and cumulated rain are below $1 \mathrm{~d}$ and $50 \mathrm{~mm}$, respectively, similar to what was reported for extreme desert floods by Tarolli et al. (2012). As observed in Syed et al. (2003), the storm centroid is concentrated around the centroid of the catchment, as indicated by $\Delta_{1}$ around values of 1 . However, in deserts it is not uncommon to have rainfall concentrated in two different parts of the basin, as indicated by $\Delta_{2}>1$, implying relatively small rain cells compared to the basins. On mixed basins, because of their morphology and climatology, we observe a strong concentration of rainfall in the Mediterranean headwater $\left(\Delta_{1}>1\right)$, which can eventually cover a relatively large portion of the basin. If we restrict the observations to floods with return period above 5 years (dots in Fig. 4), our sample becomes too small to draw conclusions, but we can draw some interesting qualitative observations. Compared to other frequencies, intense Mediterranean floods are characterized by higher rainfall depth (median $126 \mathrm{~mm}$ ), while the other properties are not much different. Compared to other frequencies, intense desert floods are also characterized by slightly higher rainfall depth (median $36 \mathrm{~mm}$ ), but in conjunction with higher maximum rain intensities $\left(29 \mathrm{~mm} \mathrm{~h}^{-1}\right)$, and rain core depth $(9 \mathrm{~mm})$. This points at the importance of rainfall depth in the development of intense floods for the Mediterranean environment, while in deserts the characteristics of intense rainfall are also important drivers.

\subsection{Flood characterization: runoff}

The properties of flood hydrographs in the three regions, and their relations with rainfall at the storm scale, are reported in Fig. 5. As in Marchi et al. (2010) the lag time is defined as the temporal delay between the centroid of the rainfall before the runoff peak and the time of the peak. As noted in Sect. 2.4, note that the uncertainty we have on the hydrograph time could affect this statistic. The runoff coefficient is calculated as the ratio between surface runoff and rainfall, and it requires the separation of the event hydrograph into direct runoff and baseflow. This separation was done applying the recursive digital filter described in Arnold and Allen (1999), a one-parameter automated filter. This geometric method has proven to be consistent between different catchments, even if the slower part of runoff can sometimes be included under baseflow. The baseflow fraction is calculated as the volume of baseflow to runoff, which in some basins can be affected by water-retention structures. The peak flow to runoff volume ratio is obtained dividing the peak discharge by the runoff volume, and it is a descriptor of the hydrograph shape.

Figure 5 shows that, despite having less rainfall in shorter durations, desert basins have event-based runoff coefficients, unit peak discharges and propagation times comparable to Mediterranean basins. The results are similar to Saharia et al. (2017), where floods in the arid southwestern United States have been found to have unit peak discharge comparable with other climates. However, it should be noted that the highest unit peak discharges are 1 order of magnitude lower than what was observed in Saharia et al. (2017). For extreme floods, desert basins of our area have been observed to have peak discharges even higher than the northern Mediterranean region (Tarolli et al., 2012). Lag times are comparable, but Ben-Zvi et al. (1991) observed that the correlation between travel time and discharge is significantly different between our Mediterranean and desert regions. Figure 5 highlights instead a significant difference in peak to runoff ratio, number of runoff peaks and flood duration, indicating differences in hydrograph shape between the two climates. Analyzing extreme storms, Tarolli et al. (2012) reported similar runoff coefficients between the arid east and the western Mediterranean, with a mean value of 0.32 . As expected, in Fig. 5 runoff coefficients for moderate floods are lower but in a few cases comparable to extreme events. Most desert basins are known not to have any baseflow, as confirmed by the very low baseflow fractions observed. Instead, in Mediterranean basins, baseflow can last for few days after the storm and significantly contribute to the total runoff volume, bringing the annual runoff coefficient to higher values than arid areas. The mixed region shows flood properties closer to desert than Mediterranean in terms of flood duration, hydrograph shape and baseflow component, but with even lower runoff coefficients. The low runoff coefficients are in line with what reported by Ries et al. (2017) for an experimental area nearby. As we did in Sect. 3.1, if we restrict 

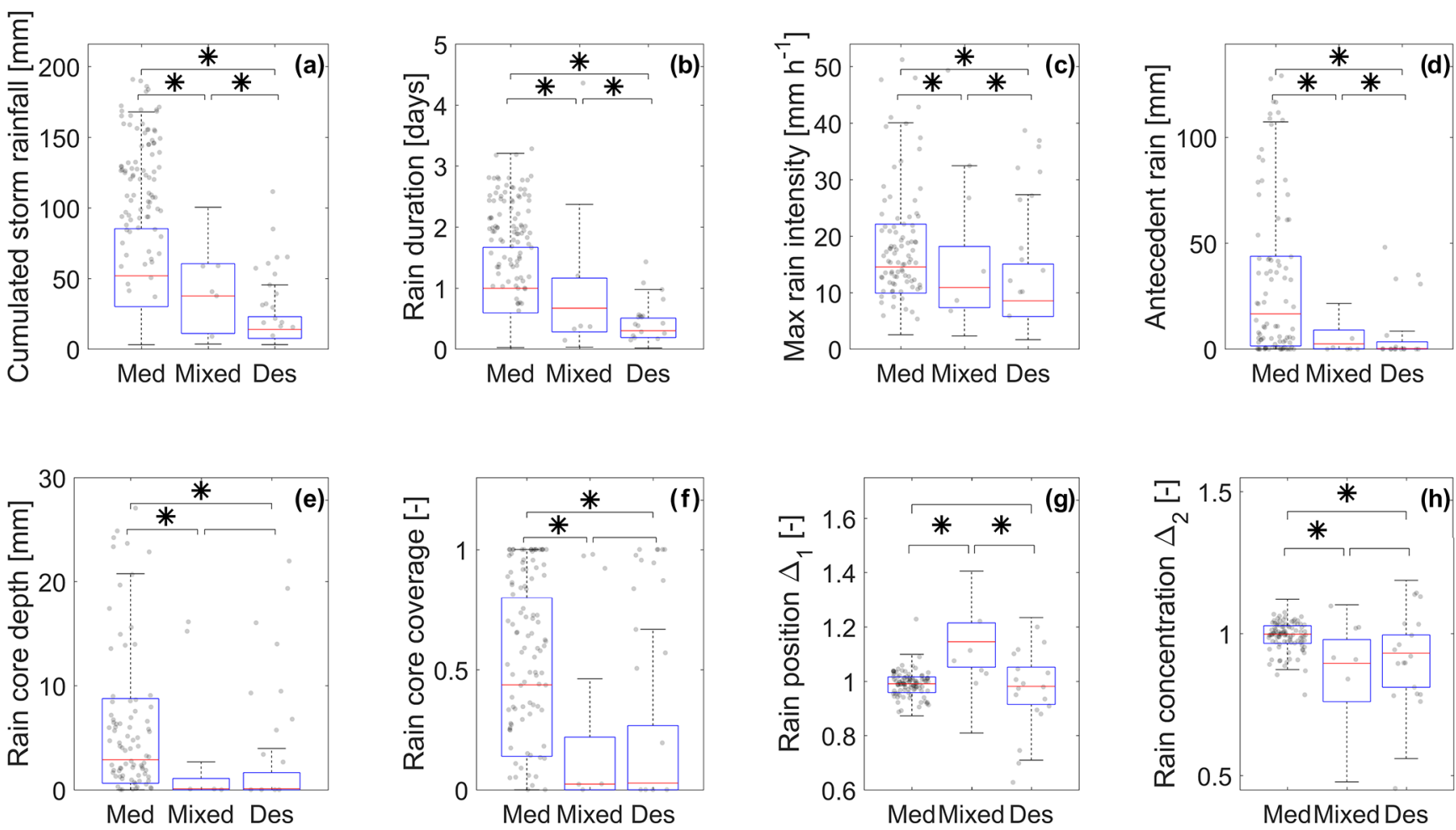

Figure 4. Boxplots showing the distribution of event rainfall properties in the three climate classes. The asterisk describes distributions with a statistically different median (Wilcoxon test, $p$ value $<0.05$ ). Black dots represent floods with more than 5 years of return period; outliers are not presented.

the observations to floods with more than 5 years of return period (dots in Fig. 5), we can draw some qualitative result. Intense floods of both Mediterranean and desert areas show higher durations (median around 4.5 and $1.5 \mathrm{~d}$, respectively) and runoff coefficients (median 0.28 and 0.17 ) compared to events with lower frequency. Despite the higher values, the relation of the factors between the two climates does not change much. Compared with lower intensities, floods with high peak discharge in Mediterranean areas are characterized by higher rainfall volumes, duration and runoff coefficients, indicating a much higher runoff volume and a longer development. Instead, floods with higher peak discharge in deserts have mostly higher runoff coefficients, while the shape of the hydrograph does not appear to be very different from more frequent events.

\subsection{Main factors related to peak discharge and runoff generation}

The unit peak discharge and runoff coefficient are two important parameters to characterize basin response. In order to highlight what factors are related to these two parameters, we analyzed their correlations with other storm and basin properties separately for each region (Fig. 6). From this analysis we cannot detect causality, but we can characterize different behaviors between the regions and suggest possible interactions. The parameters considered are MAP; relief ratio as in Sect. 2.3; amount of rainfall in the $10 \mathrm{~d}$ before the flood-generating storm (Ant. Rain); mean catchment storm rainfall (Rain depth); maximum local hourly rain intensity on $3 \mathrm{~km} \times 3 \mathrm{~km}$, as in Fig. 4 (Rain Intensity); rainfall depth of the storm core, as in Fig. 4 (rain core depth); and rain position, as in Fig. 4.

Unit peak discharge in Mediterranean basins is correlated mostly with rainfall depth, rain core depth and antecedent conditions (Fig. 6a), suggesting an importance of soil moisture for the development of the flood peak. Rinat et al. (2018) suggest that this is true for moderate storms, while during intense storms most of the basin is saturated and runoff peak is correlated to rainfall intensity. In desert and mixed basins the high correlation with rain properties, and in particular storm core, suggests that representing the most intense fraction of rainfall is key to correctly represent flood peak, as shown by Belachsen et al. (2017) and Morin and Yakir (2014). In desert basins, and to a minor extent in Mediterranean, mean catchment rain is correlated with the depth of the storm core, while in mixed catchments it is not. For this reason, it is interesting to note that rain core depth in mixed basins is much more important than mean catchment rainfall. Syed et al. (2003) in a similar setup, but on a single arid basin, also found a high correlation between storm core properties and peak rate. Rain 

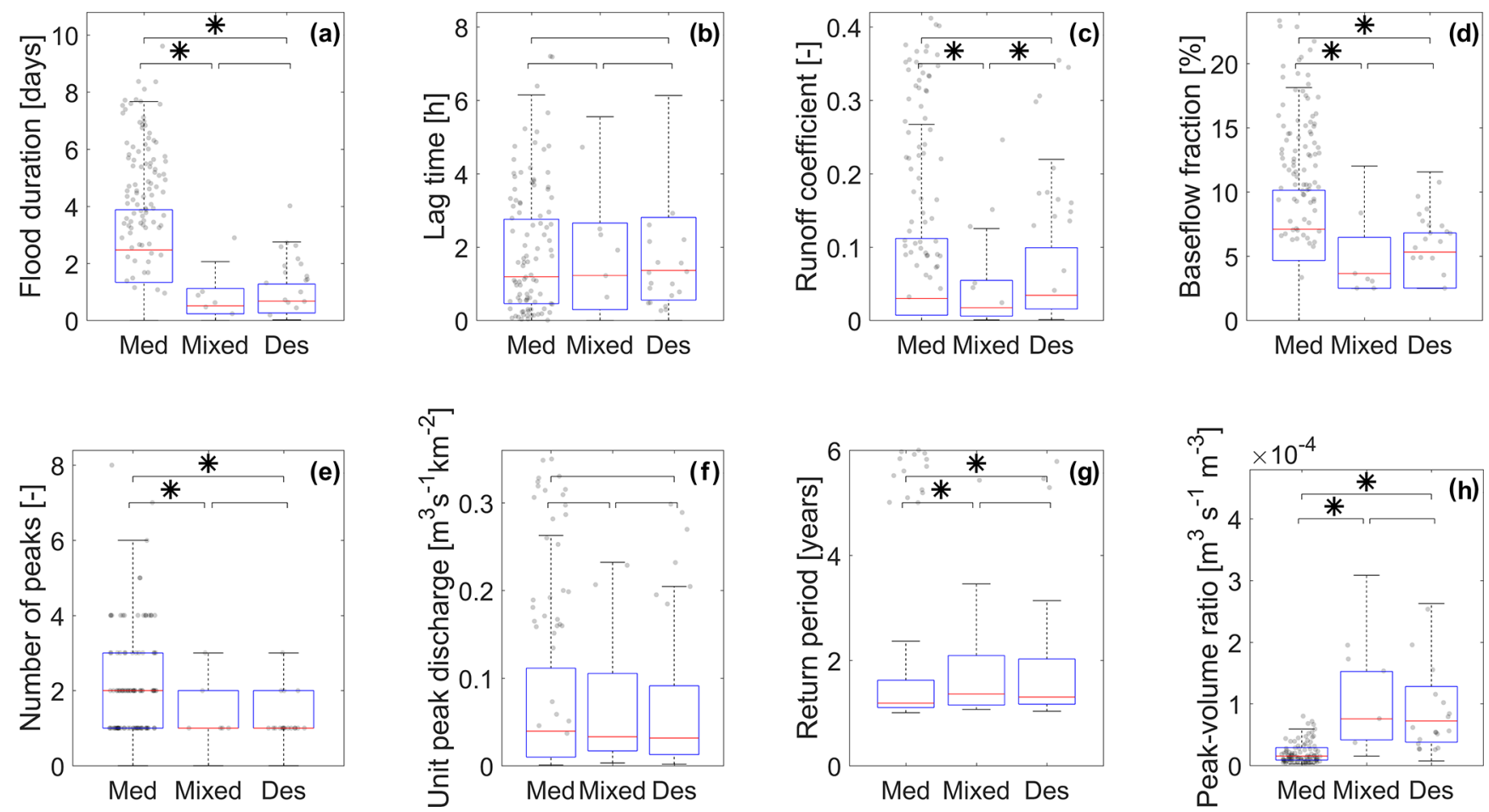

Figure 5. Boxplots showing the distribution of event runoff properties in the three climate classes. The asterisk describes distributions with a different median (Wilcoxon test, $p$ value $<0.05$ ). Black dots represent floods with more than 5 years of return period; outliers are not presented.
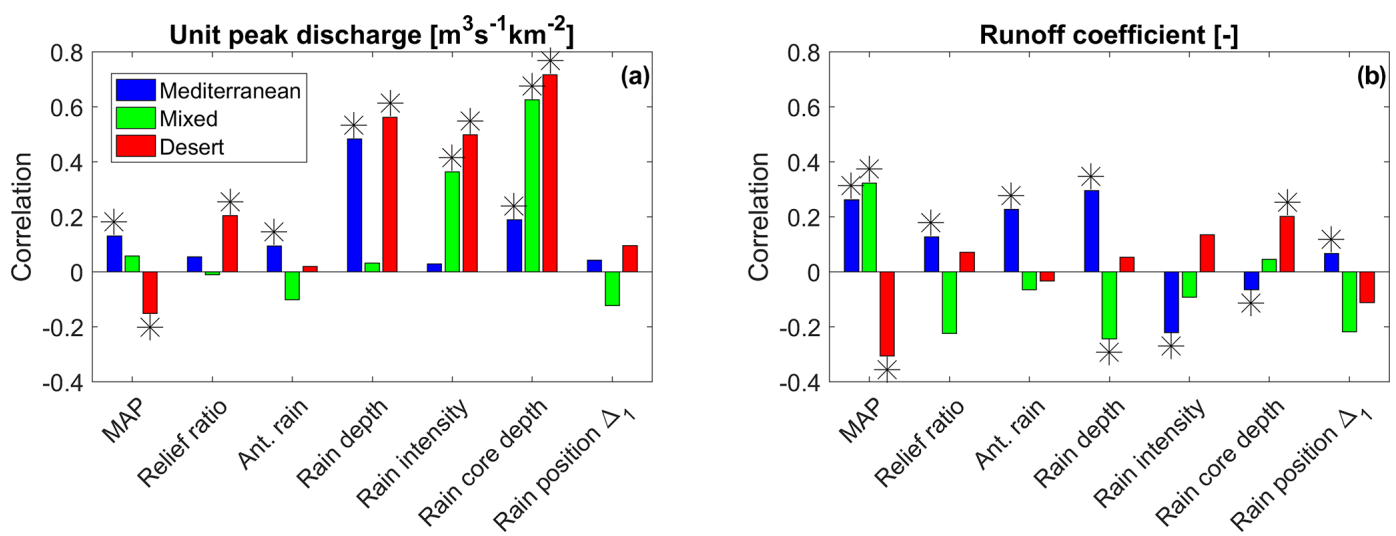

Figure 6. Pearson correlations between unit peak discharge and other parameters among floods of different regions. The asterisks indicate statistically significant correlations (Wilcoxon test, $p$ value $<0.05$ ).

position does not seem to have a significant impact on peak discharge in any of the analyzed cases.

In Mediterranean basins, high runoff coefficients are related to high rain depth, high MAP and high antecedent rain (Fig. 6b), indicating a strong importance of soil moisture in runoff generation. As observed in other semi-arid regions, this could support a combined flow generation, where runoff is produced after the partial saturation of the topsoil (Cantón et al., 2011). High soil moisture can also improve the connectivity of runoff-generating areas (Marchamalo et al.,
2016). In Mediterranean areas rainfall volume is often observed to influence runoff coefficients (Bracken et al., 2008; Kirkby et al., 2005). Tarolli et al. (2012) found no correlation between the runoff coefficient and rain depth for extreme events in Mediterranean and arid environments, suggesting that during extreme events rain intensity has a stronger influence on the amount of runoff produced. Marchi et al. (2010) for extreme floods data in different climatic regions and Castillo et al. (2003) with a simulation approach in a semi-arid area found an influence of antecedent conditions 

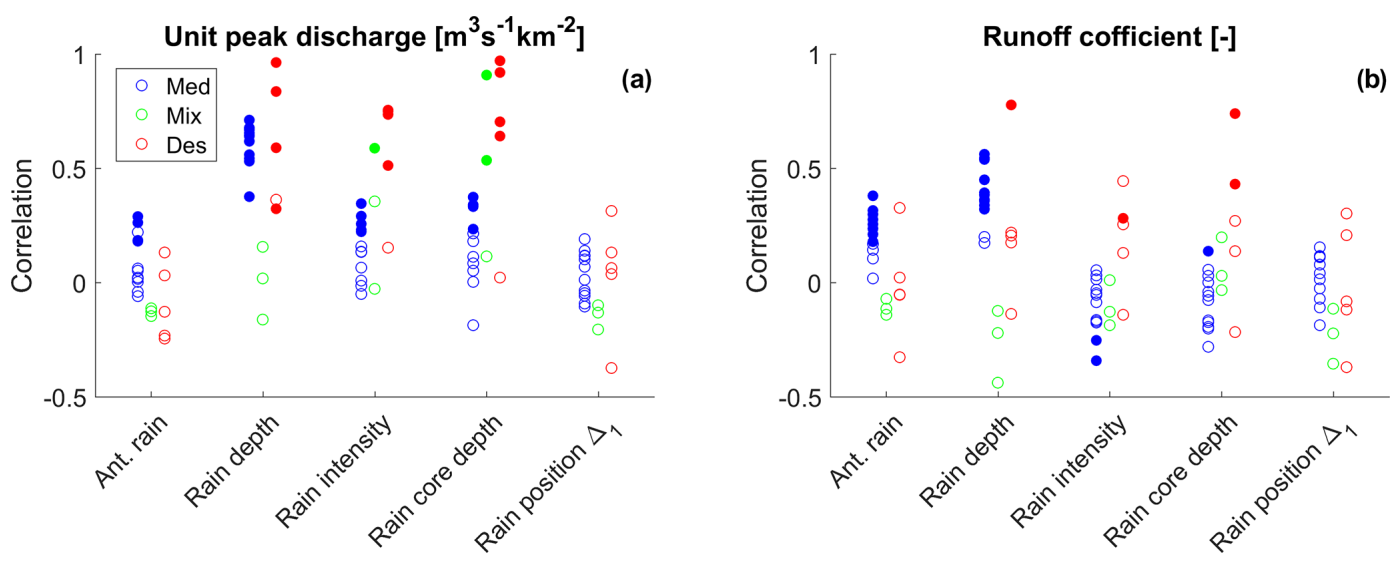

Figure 7. Correlations of the unit peak discharge and runoff coefficient for each basin with more than 15 floods. Each dot represents one basin and filled dots indicate statistically significant correlations (Wilcoxon test, $p$ value $<0.05$ ).

on the runoff coefficient, and both suggested that the effect could be higher for moderate floods. Rainfall depth in desert basins has a low impact on runoff coefficients while the properties of the storm core are more important, in accord with what was found by Syed et al. (2003) and Yang et al. (2017). These characteristics could be attributed to runoff generated by infiltration excess, as is often observed in arid environments (Martínez-Mena et al., 1998; Wheater et al., 2007). The relatively high negative correlation with MAP is also interesting. In arid regions rainfall is often pointed out as the most important variable for hydrological models (Hughes, 2007; Kite and Pietroniro, 1996). Yair and Kossovsky (2002) argue that runoff generation and rate are primarily controlled by surface properties rather than by the storm rain amount. Our results indicate that the storm core properties and annual rain amount are definitely important for runoff production, but with significant differences between arid and Mediterranean regions. A possible explanation is that, in arid environments, a slight increase in annual precipitation causes modifications in the soil and development of vegetation patches. This is linked with a significant increase in infiltration capacity (Faulkner, 1990; HilleRisLambers et al., 2001; Puigdefábregas, 2005; Zuazo and Pleguezuelo, 2009); a significant reduction of runoff connectivity (Sandercock and Hooke, 2006); and, consequently, a reduction of the runoff coefficients of single storms. The relation between the runoff coefficient and rainfall distance from the outlet is harder to interpret. Syed et al. (2003) found a negative correlation between rainfall distance from the outlet and runoff coefficient, suggesting of the presence of transmission losses. In the overall data this relation is not clear, but large differences in transmission losses among desert basins have been observed (Shentsis et al., 1999), and an analysis on single basins could be more appropriate.

In Fig. 6 we have treated the three regions as homogeneous, correlating different factors with the main hydrograph parameters. To verify this assumption, we can analyze the correlations on single basins, even if data availability limits this analysis only to a fraction of them. In Fig. 7 we have selected basins with more than 15 floods and analyzed the correlations presented for Fig. 6. Additionally, most studies of flood characterization in dry areas are based on a limited number of basins or events. This analysis allows us to understand what the variability in the results among basins of the same region can be.

The correlations with unit peak discharge seem relatively consistent with the findings of the previous section. The dispersion among basins is smaller in Mediterranean areas, maybe also because of the larger average number of events, and is larger in the mixed and desert regions, but the directions of the correlations are relatively consistent. This indicates that the processes shaping peak discharge are similar within the climatic regions. The correlation with the runoff coefficient seems consistent among Mediterranean basins but shows a wider variety of behavior among desert basins. The influence of rain properties on the runoff coefficient of desert basins is very scattered. The runoff coefficient is well correlated with rainfall properties in a few basins, while in others it is not. This could indicate a difference in processes shaping runoff coefficients within desert areas. A special note can be made for the correlation with rain distance from the outlet. Even if statistically non-significant, one basin does show a negative correlation $(-0.37)$, as it would be expected in basins with substantial transmission losses. This basin is the Zin, where Shentsis et al. (1999) estimated transmission losses to be comparable at an annual scale with catchment runoff, and more than $40 \%$ of the streams run over alluvium. However, nearby basins that should also be affected show a slight positive correlation, proving this analysis to be somehow unreliable for the detection of transmission losses in the current setup. 


\section{Conclusions}

The observation of flood properties at the catchment scale points out the integrated effect of processes that are often observed at the plot scale but whose interactions to shape the catchment response are difficult to predict. The steep climatic gradient in the study area allowed us to compare flood properties in different climates within the same monitoring systems. The fact that radar and stream gauges belong to the same networks ensures a relative data homogeneity and allows us to highlight the differences in runoff response between climates. It should be noted that these differences are limited to moderate intensity floods since extreme events are very rare in stream gauge network. Despite the large uncertainties, which are inevitable in this kind of analysis, the large sample allows us to recognize a few common patterns for moderate floods in the regions analyzed, verifying the consistency across multiple basins.

1. In Mediterranean basins runoff peaks and coefficients are connected mostly with rainfall volume, with antecedent precipitation having also a significant role. This can resemble runoff generation through the saturation of the topsoil or a landscape with limited connectivity of runoff sources, as described in Cantón et al. (2011). Remarkably, most Mediterranean basins show similar correlations with flood properties, indicating relatively uniform runoff processes.

2. Despite the lower rainfall duration and depth, floods in desert areas display unit peak discharges, lag time and event-based runoff coefficients comparable with the Mediterranean region. Peak discharge in deserts is strongly correlated with rainfall properties, particularly storm core. Drivers of runoff coefficients, instead, seem to be strongly site-specific. A possible explanation from plot-scale experimental studies, supported by our results, is that hyper-arid catchments are more impermeable than arid ones. A slight increase in mean annual rainfall allows a significant increase in infiltration capacity and a decrease in the event runoff coefficients. This variability can be difficult to capture through experimental studies, where only few basins are analyzed, and should be considered in experimental designs.

3. Despite the small sample, we can draw some indications also for mixed basins. These basins show unique rainfall properties, with volumes and durations between Mediterranean and desert but highly concentrated in the headwater. They often lack baseflow at the outlet and display very low runoff coefficients. Storm core properties are related to peak discharge, while, because of the strong rainfall concentration, mean catchment rainfall does not appear to be significant.

4. Evidence of transmission losses at the catchment scale seems difficult to find even in areas where they are known to be significant. A possible explanation is that the sample is not large enough to isolate the effect of transmission losses over runoff volume from other effects, but this does not imply that they are not present.

5. Floods with higher return period have different properties compared to events with lower intensity. In Mediterranean climate these floods are characterized by higher rainfall volume, while in deserts intense floods are also characterized by higher local rainfall intensity and higher volume of the storm core. Runoff coefficients of intense floods are significantly higher for both climates.

Considering the conclusions above, the main processes of runoff production at the catchment scale in Mediterranean areas are connected to rainfall volume and soil moisture. To model floods accurately it is important to capture rainfall volume, its temporal distribution and the pattern of hydrological properties within the landscape. The use of rainfall-runoff models developed for temperate areas, including runoff production from saturation excess, could be effective for these areas. In desert catchments, instead, runoff production is mainly connected with local rain intensity and with soil properties. Rainfall resolution below $10 \mathrm{~km}^{2}$ is fundamental to describe the core of convective cells well, and a rain gauge network is generally not able to provide such a resolution. Hydrological models should include runoff production through infiltration excess, together with a spatial description of local rainfall intensities and soil properties.

The study of rainfall-runoff properties over the eastern Mediterranean presented important challenges. The main ones can be identified as the availability of data in different geographical areas and the high data uncertainties. Regarding rainfall uncertainties, soon dual-polarization radar could improve the estimation of strong rainfall and separate the occurrence of hail. Regarding discharge uncertainties, estimations have been reduced in the last decades, but errors related to the estimation of high flows are still expected to be significant in the coming years (Di Baldassarre and Montanari, 2009). Standardized methods for post-event estimation, such as the ones proposed by Amponsah et al. (2016), could help to reduce and quantify these uncertainties for high flows.

Data availability. Processed data are available through the HyMeX archive (Zoccatelli et al., 2019, https://doi.org/10.6096/MISTRALS-HyMeX.1501).

Author contributions. FM and DZ prepared the data set. DZ and EM conceptualized and performed the analysis. DZ wrote the manuscript with contributions from MA and YR. FM and JAS provided insights on the rainfall data and the relations with intense events. All authors reviewed the manuscript and contributed to its development. 
Competing interests. The authors declare that they have no conflict of interest.

Special issue statement. This article is part of the special issue "Hydrological cycle in the Mediterranean (ACP/AMT/GMD/HESS/NHESS/OS inter-journal SI)". It is not associated with a conference.

Acknowledgements. This study was funded by the NSF-BSF grant BSF 2016953, by the Israel Science Foundation (grant no. 1069/18), by the BARD project (IS-5124-18) and by a Google gift grant. This study is a contribution to the PALEX project Paleohydrology and Extreme Floods from the Dead Sea ICDP Core and is a contribution to the HyMeX program.

Financial support. This research has been supported by the United States-Israel Binational Science Foundation (grant no. 2016953), the Israel Science Foundation (grant no. 1069/18), and the United States-Israel Binational Agricultural Research and Development Fund (grant no. 5124-18).

Review statement. This paper was edited by Giuseppe Tito Aronica and reviewed by two anonymous referees.

\section{References}

Abrahams, A. D. and Parsons, A. J.: Relation between infiltration and stone cover on a semiarid hillslope, southern Arizona, J. Hydrol., 122, 49-59, https://doi.org/10.1016/0022-1694(91)90171D, 1991.

Amponsah, W., Marchi, L., Zoccatelli, D., Boni, G., Cavalli, M., Comiti, F., Crema, S., Lucía, A., Marra, F., and Borga, M.: Hydrometeorological characterization of a flash flood associated with major geomorphic effects: Assessment of peak discharge uncertainties and analysis of the runoff response, J. Hydrometeorol., 17, 3063-3077, https://doi.org/10.1175/JHM-D-16-0081.1, 2016.

Amponsah, W., Ayral, P.-A., Boudevillain, B., Bouvier, C., Braud, I., Brunet, P., Delrieu, G., Didon-Lescot, J.-F., Gaume, E., Lebouc, L., Marchi, L., Marra, F., Morin, E., Nord, G., Payrastre, O., Zoccatelli, D., and Borga, M.: Integrated highresolution dataset of high-intensity European and Mediterranean flash floods, Earth Syst. Sci. Data, 10, 1783-1794, https://doi.org/10.5194/essd-10-1783-2018, 2018.

Armon, M., Dente, E., Smith, J. A., Enzel, Y., and Morin, E.: Synoptic-scale control over modern rainfall and flood patterns in the Levant drylands with implications for past climates, J. Hydrometeorol., 19, 1077-1096, https://doi.org/10.1175/JHMD-18-0013.1, 2018.

Arnold, J. G. and Allen, P. M.: Automated methods for estimating baseflow and groundwater recharge from streamflow records, J. Am. Water Resour. As., 35, 411-424, https://doi.org/10.1111/j.1752-1688.1999.tb03599.x, 1999.
Bahat, Y., Grodek, T., Lekach, J., and Morin, E.: Rainfall-runoff modeling in a small hyper-arid catchment, J. Hydrol., 373, 204217, https://doi.org/10.1016/j.jhydrol.2009.04.026, 2009.

Belachsen, I., Marra, F., Peleg, N., and Morin, E.: Convective rainfall in a dry climate: relations with synoptic systems and flashflood generation in the Dead Sea region, Hydrol. Earth Syst. Sci., 21, 5165-5180, https://doi.org/10.5194/hess-21-5165-2017, 2017.

Ben-Zvi, A., Massoth, S., and Schick, A. P.: Travel time of runoff crests in Israel, J. Hydrol., 122, 309-320, https://doi.org/10.1016/0022-1694(91)90185-K, 1991.

Bergkamp, G.: A hierarchical view of the interactions of runoff and infiltration with vegetation and microtopography in semiarid shrublands, Catena, 33, 201-220, https://doi.org/10.1016/S03418162(98)00092-7, 1998.

Beven, K. J.: Rainfall-runoff modelling: the primer, Rainfall-Runoff Modelling: The Primer, Second Edition, John Wiley \& Sons, Chichester, https://doi.org/10.1002/9781119951001, 2012.

Bracken, L. J., Cox, N. J., and Shannon, J.: The relationship between rainfall inputs and flood generation in south-east Spain, Hydrol. Process., 22, 683-696, https://doi.org/10.1002/hyp.6641, 2008.

Cantón, Y., Solé-Benet, A., de Vente, J., Boix-Fayos, C., CalvoCases, A., Asensio, C., and Puigdefábregas, J.: A review of runoff generation and soil erosion across scales in semiarid south-eastern Spain, J. Arid Environ., 75, 1254-1261, https://doi.org/10.1016/j.jaridenv.2011.03.004, 2011.

Castillo, V. M., Gómez-Plaza, A., and Martínez-Mena, M.: The role of antecedent soil water content in the runoff response of semiarid catchments: A simulation approach, J. Hydrol., 284, 114130, https://doi.org/10.1016/S0022-1694(03)00264-6, 2003.

Cherlet, M., Hutchinson, C., Reynolds, J., Hill, J., Sommer, S., and von Maltitz, G.: World Atlas of Desertification, Publication Office of the European Union, Luxembourg, 3rd edn., https://doi.org/10.2760/9205, 2018.

Costa, J. E.: Hydraulics and basin morphometry of the largest flash floods in the conterminous United States, J. Hydrol., 93, 313338, https://doi.org/10.1016/0022-1694(87)90102-8, 1987.

Dayan, U., Ricaud, P., Zbinden, R., and Dulac, F.: Atmospheric pollution over the eastern Mediterranean during summer - a review, Atmos. Chem. Phys., 17, 13233-13263, https://doi.org/10.5194/acp-17-13233-2017, 2017.

De Vries, A. J., Tyrlis, E., Edry, D., Krichak, S. O., Steil, B., and Lelieveld, J.: Extreme precipitation events in the Middle East: Dynamics of the Active Red Sea Trough, J. Geophys. Res.Atmos., 118, 7087-7108, https://doi.org/10.1002/jgrd.50569, 2013.

Di Baldassarre, G. and Montanari, A.: Uncertainty in river discharge observations: a quantitative analysis, Hydrol. Earth Syst. Sci., 13, 913-921, https://doi.org/10.5194/hess-13-913-2009, 2009.

Dunkerley, D. L.: Surface stone cover on desert hillslopes; parameterizing characteristics relevant to infiltration and surface runoff, Earth Surf. Proc. Land., 20, 207-218, https://doi.org/10.1002/esp.3290200303, 1995.

Dunne, T., Zhang, W., and Aubry, B. F.: Effects of Rainfall, Vegetation, and Microtopography on Infiltration and Runoff, Water Resour. Res., 27, 2271-2285, https://doi.org/10.1029/91WR01585, 1991. 
Farquharson, F., Meigh, J., and Sutcliffe, J.: Regional flood frequency analysis in arid and semi-arid areas, J. Hydrol., 138, 487501, https://doi.org/10.1016/0022-1694(92)90132-F, 1992.

Faulkner, H.: Vegetation cover density variations and infiltration patterns on piped alkali sodic soils: implications for the modelling of overland flow in semi-arid areas, Vegetation and erosion, Processes and environments., 317-346, 1990.

Faurès, J. M., Goodrich, D. C., Woolhiser, D. A., and Sorooshian, S.: Impact of small-scale spatial rainfall variability on runoff modeling, J. Hydrol., 173, 309-326, https://doi.org/10.1016/0022-1694(95)02704-S, 1995.

Feng, S. and Fu, Q.: Expansion of global drylands under a warming climate, Atmos. Chem. Phys., 13, 10081-10094, https://doi.org/10.5194/acp-13-10081-2013, 2013.

Fiener, P. and Auerswald, K.: Spatial variability of rainfall on a sub-kilometre scale, Earth Surf. Proc. Land., 34, 848-859, https://doi.org/10.1002/esp.1779, 2009.

Francis, C. F. and Thornes, J. B.: Runoff hydrographs from three Mediterranean vegetation cover types, Vegetation and erosion, Processes and Environments, 363-384, 1990.

Goldreich, Y.: The spatial distribution of annual rainfall in Israel - a review, Theor. Appl. Climatol., 50, 45-59, https://doi.org/10.1007/BF00864902, 1994.

Goldreich, Y.: The climate of Israel: observation, research and application, Springer, 2003.

Goodrich, D. C., Chehbouni, A., Goff, B., MacNish, B., Maddock, T., Moran, S., Shuttleworth, W. J., Williams, D. G., Watts, C., Hipps, L. H., Cooper, D. I., Schieldge, J., Kerr, Y. H., Arias, H., Kirkland, M., Carlos, R., Cayrol, P., Kepner, W., Jones, B., Avissar, R., Begue, A., Bonnefond, J. M., Boulet, G., Branan, B., Brunel, J. P., Chen, L. C., Clarke, T., Davis, M. R., DeBruin, H., Dedieu, G., Elguero, E., Eichinger, W. E., Everitt, J., Garatuza-Payan, J., Gempko, V. L., Gupta, H., Harlow, C., Hartogensis, O., Helfert, M., Holifield, C., Hymer, D., Kahle, A., Keefer, T., Krishnamoorthy, S., Lhomme, J. P., Lagouarde, J. P., Lo Seen, D., Luquet, D., Marsett, R., Monteny, B., Ni, W., Nouvellon, Y., Pinker, R., Peters, C., Pool, D., Qi, J., Rambal, S., Rodriguez, J., Santiago, F., Sano, E., Schaeffer, S. M., Schulte, M., Scott, R., Shao, X., Snyder, K. A., Sorooshian, S., Unkrich, C. L., Whitaker, M., and Yucel, I.: Preface paper to the SemiArid Land-Surface-Atmosphere (SALSA) Program special issue, Agr. Forest Meteorol., 105, 3-20, https://doi.org/10.1016/S01681923(00)00178-7, 2000.

Graf, W.: Fluvial Processes Dryland Rivers, Springer-Verlag, New York, 1988.

Greenbaum, N., Ben-Zvi, A., Haviv, I., and Enzel, Y.: The hydrology and paleohydrology of the Dead Sea tributaries, Geol. Soc. Am. S., 401, 63-93, https://doi.org/10.1130/2006.2401(05), 2006.

Grodek, T., Jacoby, Y., Morin, E., and Katz, O.: Effectiveness of exceptional rainstorms on a small Mediterranean basin, Geomorphology, 159-160, 156-168, https://doi.org/10.1016/j.geomorph.2012.03.016, 2012.

HilleRisLambers, R., Rietkerk, M., van den Bosch, F., Prins, H. H. T., and de Kroon, H.: Vegetation Pattern Formation in Semi-Arid Grazing Systems, Ecology, 82, 50-61, https://doi.org/10.2307/2680085, 2001.

Hughes, D. A.: Modelling semi-arid and arid hydrology and water resources: The Southern African experience, Hydro- logical Modelling in Arid and Semi-Arid Areas, 29-40, https://doi.org/10.1017/CBO9780511535734.004, 2007.

Israeli Hydrological Service: Annual hydrological report for Israel 2013/2014, Jerusalem, 2016 (in Hebrew).

Tongway, D. J. and Ludwig, J. A.: Small-scale resource heterogeneity in semi-arid landscapes, Pacific Conservation Biology, 1, 201-208, https://doi.org/10.1071/PC940201, 1994.

Kahana, R., Ziv, B., Enzel, Y., and Dayan, U.: Synoptic climatology of major floods in the Negev Desert, Israel, Int. J. Climatol., 22, 867-882, https://doi.org/10.1002/joc.766, 2002.

Katz, R. W., Parlange, M. B., and Naveau, P.: Statistics of extremes in hydrology, Adv. Water Resour., 25, 1287-1304, https://doi.org/10.1016/S0309-1708(02)00056-8, 2002.

Keppel, R. and Renard, K.: Transmission losses in ephemeral stream beds, J. Hydr. Eng. Div.-ASCE, 88, 59-68, 1962.

Kirkby, M. J., Bracken, L. J., and Shannon, J.: The influence of rainfall distribution and morphological factors on runoff delivery from dryland catchments in SE Spain, Catena, 62, 136-156, https://doi.org/10.1016/j.catena.2005.05.002, 2005.

Kite, G. W. and Pietroniro, A.: Remote sensing applications in hydrological modelling, Hydrolog. Sci. J., 41, 563-591, https://doi.org/10.1080/02626669609491526, 1996.

Köppen, W.: Das geographisca System der Klimate, in: Handbuch der Klimatologie, 1-44, 1936.

Ludwig, J. A. and Tongway, D. J.: Spatial organisation of landscapes and its function in semi-arid woodlands, Australia, Landscape Ecol., 10, 51-63, https://doi.org/10.1007/BF00158553, 1995.

Marchamalo, M., Hooke, J. M., and Sandercock, P. J.: Flow and Sediment Connectivity in Semi-arid Landscapes in SE Spain: Patterns and Controls, Land Degrad. Dev., 27, 1032-1044, https://doi.org/10.1002/ldr.2352, 2016.

Marchi, L., Borga, M., Preciso, E., and Gaume, E.: Characterisation of selected extreme flash floods in Europe and implications for flood risk management, J. Hydrol., 394, 118-133, https://doi.org/10.1016/j.jhydrol.2010.07.017, 2010.

Marra, F. and Morin, E.: Use of radar QPE for the derivation of Intensity-Duration-Frequency curves in a range of climatic regimes, J. Hydrol., 531, 427-440, https://doi.org/10.1016/j.jhydrol.2015.08.064, 2015.

Marra, F. and Morin, E.: Autocorrelation structure of convective rainfall in semiarid-arid climate derived from highresolution X-Band radar estimates, Atmos. Res., 200, 126-138, https://doi.org/10.1016/j.atmosres.2017.09.020, 2018.

Martínez-Mena, M., Albaladejo, J., and Castillo, V. M.: Factors influencing surface runoff generation in a Mediterranean semi-arid environment: Chicamo watershed, SE Spain, Hydrol. Process., 12, 741-754, https://doi.org/10.1002/(SICI)10991085(19980430)12:5<741::AID-HYP622>3.0.CO;2-F, 1998.

McDermott, G. E. and Pilgrim, D. H.: A design flood method for arid western New South Wales based on bankfull estimates, Civil Engineering Transactions, 25, 114-120, 1983.

Meirovich, L., Ben-Zvi, A., Shentsis, I., and Yanovich, E.: Frequency and magnitude of runoff events in the arid Negev of Israel, J. Hydrol., 207, 204-219, https://doi.org/10.1016/S00221694(98)00135-8, 1998.

Morin, E. and Yakir, H.: Hydrological impact and potential flooding of convective rain cells in a semi- 
arid environment, Hydrolog. Sci. J., 59, 1353-1362, https://doi.org/10.1080/02626667.2013.841315, 2014.

Morin, E., Goodrich, D. C., Maddox, R. A., Gao, X., Gupta, H. V., and Sorooshian, S.: Spatial patterns in thunderstorm rainfall events and their coupling with watershed hydrological response, Adv. Water Resour., 29, 843-860, https://doi.org/10.1016/j.advwatres.2005.07.014, 2006.

Morin, E., Grodek, T., Dahan, O., Benito, G., Kulls, C., Jacoby, Y., Langenhove, G. V., Seely, M., and Enzel, Y.: Flood routing and alluvial aquifer recharge along the ephemeral arid Kuiseb River, Namibia, J. Hydrol., 368, 262-275, https://doi.org/10.1016/J.JHYDROL.2009.02.015, 2009a.

Morin, E., Jacoby, Y., Navon, S., and Bet-Halachmi, E.: Towards flash-flood prediction in the dry Dead Sea region utilizing radar rainfall information, Adv. Water Resour., 32, 1066-1076, https://doi.org/10.1016/j.advwatres.2008.11.011, 2009b.

Osborn, H. B., Lane, L. J., and Hundley, J. F.: Optimum gaging of thunderstorm rainfall in southeastern Arizona, Water Resour. Res., 8, 259-265, https://doi.org/10.1029/WR008i001p00259, 1972.

Peel, M. C., Finlayson, B. L., and McMahon, T. A.: Updated world map of the Köppen-Geiger climate classification, Hydrol. Earth Syst. Sci., 11, 1633-1644, https://doi.org/10.5194/hess-11-16332007, 2007.

Peleg, N. and Morin, E.: Convective rain cells: Radar-derived spatiotemporal characteristics and synoptic patterns over the eastern Mediterranean, J. Geophys. Res.-Atmos., 117, D15116, https://doi.org/10.1029/2011JD017353, 2012.

Pilgrim, D., Chapman, T., and Doran, D.: Problems of rainfallrunoff modelling in arid and semiarid regions, Hydrolog. Sci. J., 33, 379-400, 1988.

Poesen, J., Ingelmo-Sanchez, F., and Mucher, H.: The hydrological response of soil surfaces to rainfall as affected by cover and position of rock fragments in the top layer, Earth Surf. Proc. Land., 15, 653-671, https://doi.org/10.1002/esp.3290150707, 1990.

Puigdefábregas, J.: The role of vegetation patterns in structuring runoff and sediment fluxes in drylands, Earth Surf. Proc. Land., 30, 133-147, https://doi.org/10.1002/esp.1181, 2005.

Reaney, S. M., Bracken, L. J., and Kirkby, M. J.: Use of the Connectivity of Runoff Model (CRUM) to investigate the influence of storm characteristics on runoff generation and connectivity in semi-arid areas, Hydrol. Process., 21, 894-906, https://doi.org/10.1002/hyp.6281, 2007.

Reid, I. and Frostick, L. E.: Flow dynamics and suspended sediment properties in arid zone flash floods, Hydrol. Process., 1, 239-253, https://doi.org/10.1002/hyp.3360010303, 1987.

Renard, K. G., Nichols, M. H., Woolhiser, D. A., and Osborn, H. B.: A brief background on the U.S. Department of Agriculture Agricultural Research Service Walnut Gulch Experimental Watershed, Water Resour. Res., 44, W05S02, https://doi.org/10.1029/2006WR005691, 2008.

Ries, F., Schmidt, S., Sauter, M., and Lange, J.: Controls on runoff generation along a steep climatic gradient in the Eastern Mediterranean, J. Hydrol., 9, 18-33, https://doi.org/10.1016/j.ejrh.2016.11.001, 2017.

Rinat, Y., Marra, F., Zoccatelli, D., and Morin, E.: Controls of flash flood peak discharge in Mediterranean basins and the special role of runoff-contributing areas, J. Hydrol., 565, 846-860, https://doi.org/10.1016/J.JHYDROL.2018.08.055, 2018.
Rubin, S., Ziv, B., and Paldor, N.: Tropical Plumes over Eastern North Africa as a Source of Rain in the Middle East, Mon. Weather Rev., 135, 4135-4148, https://doi.org/10.1175/2007MWR1919.1, 2007.

Safriel, U., Adeel, Z., Niemeijer, D., Puigdefabregas, J., White, R., Lal, R., Winslow, M., Ziedler, J., Prince, S., Archer, E., King, C., Shapiro, B., Wessels, K., Nielsen, T., Portnov, B., Reshef, I., Thonell, J., Lachman, E., and Mcnab, D.: Dryland Systems, in: Ecosystems and Human Well-Being: Current State and Trends Current State and Trends, Island Press, 623-662, 2005.

Saharia, M., Kirstetter, P. E., Vergara, H., Gourley, J. J., and Hong, Y.: Characterization of floods in the United States, J. Hydrol., 548, 524-535, https://doi.org/10.1016/j.jhydrol.2017.03.010, 2017.

Sandercock, P. and Hooke, J.: Strategies for reducing sediment connectivity and land degradation in desertified areas using vegetation: the RECONDES project, IAHS-AISH P., 306, 287-294, 2006.

Schick, A., Hassan, M., and Slaymaker, O.: A brief summary of a third of a century: Nahal Yael in retrospect, with some ideas for the future of catchment research, IAHS-AISH P., 261, 5-12, 2000.

Schumm, S. A.: Evolution of drainage systems and slopes in badlands at Perth Amboy, New Jersey, B. Geol. Soc. Am., 67, 597646, 1956.

Sharon, D. and Kutiel, H.: The distribution of rainfall intensity in Israel, its regional and seasonal variations and its climatological evaluation, J. Climatol., 6, 277-291, https://doi.org/10.1002/joc.3370060304, 1986.

Shentsis, I., Meirovich, L., Ben-Zvi, A., and Rosenthal, E.: Assessment of transmission losses and groundwater recharge from runoff events in a wadi under shortage of data on lateral inflow, Negev, Israel, Hydrol. Process., 13, 1649-1663, https://doi.org/10.1002/(SICI)10991085(19990815)13:11<1649::AID-HYP834>3.0.CO;2-N, 1999.

Singer, M. J. and Le Bissonnais, Y.: Importance of surface sealing in the erosion of some soils from a Mediterranean climate, Geomorphology, 24, 79-85, https://doi.org/10.1016/S0169555X(97)00102-5, 1998.

Smith, J. A., Baeck, M. L., Meierdiercks, K. L., Nelson, P. A., Miller, A. J., and Holland, E. J.: Field studies of the storm event hydrologic response in an urbanizing watershed, Water Resour. Res., 41, W10413, https://doi.org/10.1029/2004WR003712, 2005.

Smith, J. A., Cox, A. A., Baeck, M. L., Yang, L., and Bates, P.: Strange Floods: The Upper Tail of Flood Peaks in the United States, Water Resour. Res., 54, 6510-6542, https://doi.org/10.1029/2018WR022539, 2018.

Survey of Israel: Atlas of Israel - Cartography, Physical Geography, Human and Economical Geography, History, Survey of Israel, Min. of Labour, Jerusalem, 1970.

Syed, K. H., Goodrich, D. C., Myers, D. E., and Sorooshian, S.: Spatial characteristics of thunderstorm rainfall fields and their relation to runoff, J. Hydrol., 271, 1-21, https://doi.org/10.1016/S0022-1694(02)00311-6, 2003.

Tarolli, P., Borga, M., Morin, E., and Delrieu, G.: Analysis of flash flood regimes in the North-Western and South-Eastern Mediterranean regions, Nat. Hazards Earth Syst. Sci., 12, 1255-1265, https://doi.org/10.5194/nhess-12-1255-2012, 2012. 
Thornes, J. B.: The ecology of erosion, Geography, 70, 222-235, https://doi.org/10.1177/0309133310367548, 1985.

Tooth, S.: Process, form and change in dryland rivers: A review of recent research, Earth Sci. Rev., 51, 67-107, https://doi.org/10.1016/S0012-8252(00)00014-3, 2000.

Tooth, S. and Nanson, G. C.: Distinctiveness and Diversity of Arid Zone River Systems, in: Arid Zone Geomorphology: Process, Form and Change in Drylands, 3rd edn., 269-300, https://doi.org/10.1002/9780470710777.ch12, 2011.

Wheater, H., Sorooshian, S., and Sharma, K. D.: Hydrological Modelling in Arid and Semi-Arid Areas, Environmental Engineering, Cambridge University Press, https://doi.org/10.1017/CBO9780511535734, 2007.

Yair, A.: Runoff generation in a sandy area - the nizzana sands, Western Negev, Israel, Earth Surf. Proc. Land., 15, 597-609, https://doi.org/10.1002/esp.3290150703, 1990.

Yair, A. and Kossovsky, A.: Climate and surface properties: Hydrological response of small arid and semi-arid watersheds, Geomorphology, 42, 43-57, https://doi.org/10.1016/S0169555X(01)00072-1, 2002.

Yair, A. and Raz-Yassif, N.: Hydrological processes in a small arid catchment: Scale effects of rainfall and slope length, Geomorphology, 61, 155-169, https://doi.org/10.1016/j.geomorph.2003.12.003, 2004.
Yang, L., Smith, J., Baeck, M. L., Morin, E., and Goodrich, D. C.: Flash Flooding in Arid/Semi-arid Regions: Dissecting the Hydrometeorology and Hydrology of the 19 August 2014 Storm and Flood Hydroclimatology in Arizona, J. Hydrometeorol., 18, 3103-3123, https://doi.org/10.1175/JHM-D-17-0089.1, 2017.

Ziv, B., Saaroni, H., and Alpert, P.: The factors governing the summer regime of the eastern Mediterranean, Int. J. Climatol., 24, 1859-1871, https://doi.org/10.1002/joc.1113, 2004.

Zoccatelli, D., Borga, M., Viglione, A., Chirico, G. B., and Blöschl, G.: Spatial moments of catchment rainfall: rainfall spatial organisation, basin morphology, and flood response, Hydrol. Earth Syst. Sci., 15, 3767-3783, https://doi.org/10.5194/hess-15-37672011, 2011.

Zoccatelli, D., Marra, F., Armon, M., Rinat, Y., Smith, J. A., and Morin, E.: Rainfall-runoff characteristics of Desert and Mediterranean catchments in Israel, https://doi.org/10.6096/MISTRALS-HyMeX.1501, 2019.

Zuazo, V. H. D. and Pleguezuelo, C. R. R.: Soil-erosion and runoff prevention by plant covers: A review, Sustainable Agriculture, 785-811, https://doi.org/10.1007/978-90-481-2666-8_48, 2009. 